\title{
Kadınların Günlük Hayattaki İletişim Engelleri: Nitel Bir Çalışma
}

\author{
Çağla Girgin Büyükbayraktar \\ Dr. Öğr, Üyesi \\ Selçuk Üniversitesi \\ Ali Akkanat Uygulamalı Bilimler Yüksek Okulu \\ cagla.girgin@hotmail.com \\ Orcid: 0000-0001-8440-6320
}

\section{Abstract \\ Communication Obstacles of Women in Daily Life: A Qualitative Research}

The aim of this study is to determine the communication obstacles that women face in daily life. Qualitative research technique was used in this study. The purposeful sampling method was used for the determination of the sample and 38 women with different demographic characteristics were included in the study. In order to collect the data, semi-structured interview technique was used as a method. The data obtained at the end of the interviews were analyzed by content analysis technique. Some themes were identified for interpreting the data. Categories related to each theme were created. According to the results of the study, women have been facing various obstacles in the communication they establish in daiIy life. 4 themes were identified for the communication obstacles that women face in daily life; individual obstacles, fear and emotional implications, socio-psychological obstacles and language-related obstacles. These themes were then categorized. There are 10 categories in the theme of individual obstacles (mind reading, erroneous fortune-telling, catastrophizing, labeling, wishing to be understood immediately, being touchy, acting with emotions, seeking approval, being extremely remote, being mysterious). There are 8 categories in the theme of fear and emotional implications (judicial and accusatory treatment, excessive control, not paying attention to emotions, gossiping, giving nicknames, threatening and intimidating, feeling

DOI: 10.16878/gsuilet.500936 
under-pressure by the opposite sex, feeling not being heard). There are 5 categories of socio-psychological obstacles (feeling worthless, feeling inadequate, being obsessed with the past, inability to focus on the present moment, being made scapegoats, timid behavior). There are 3 categories of language-related obstacles (using long and complex sentences, excessive exaggeration, dullness).

Keywords: Women, communication, obstacle, qualitative analysis.

\section{Résumé}

\section{Les obstacles de communication à la vie quotidienne des femmes : une étude qualitative}

Cette recherche vise à identifier les blocages de communication auxquels les femmes font face à leur quotidiennes. Dans l'étude, on s'est servi de la méthode de recherche qualitative. Pour déterminer l'échantillon, la méthode d'échantillonnage intentionnelle a été employée et 38 femmes ayant des mêmes caractéristiques démographiques ont participé à l'étude. Dans la collecte des données de la recherche, on a utilisé la technique d'entretien semi-directif comme la méthode de collecte des données. Les données obtenues à la fin des entretiens ont été analysées par l'intermédiaire de la technique d'analyse de contenu. Pendant l'interprétation des données, les thèmes ont été révélés. Les catégories appropriées ont été créée pour chaque thème. Des résultats obtenus à la fin de la recherche, on a conclu que les femmes font face à des obstacles divers au cours de leurs communications quotidiennes. Pour les obstacles que les femmes font face dans leurs vies quotidiennes, 4 thèmes ont été identifiés comme les obstacles individuels : la peur et les allusions sentimentales, les obstacles socio-psychologiques et les obstacles linguistiques. Ces thèmes-ci ont été ensuite repartis en sous-catégories. On rencontre 10 sous-catégories auprès du thème "obstacles individuels " (télépathie, clairvoyance erronée, pessimisme, étiquetage, envie d'être sitôt compris, être susceptible, réagir avec ses sentiments, recherche d'approbation, froideur excessive, être mystérieuse), 8 sous-catégories auprès du thème "la peur et les allusions sentimentales" (être traitée d'une manière critiquant et accusant, être trop manipulée et examinée, ignorer les sentiments, raconter des ragots, surnommer, menace et intimidation, se sentir sous la pression du sexe opposé, deviner qu'on n'est pas écoutée) 5 sous-catégories auprès du thème "obstacles socio-psychologiques " (se sentir sans valeur, se sentir incompétente, vivre dans le passé et faute de s'orienter en ce moment, se désigner comme bouc émissaire, être gênante) et enfin 3 catégories auprès du thème "obstacles linguistiques " (faire des phrases longues et compliquées, être trop exagérée, être inexpressive)

Mots clés : Femmes, communication, obstacle, analyse qualitative. 


\section{Öz}

Bu araştırmanın amacı kadınların günlük hayatta karşılaştıkları iletişim engellerini belirlemektir. Çalışmada nitel araştırma tekniğinden yararlanılmıştır. Örneklem belirlenmesinde amaçlı örnekleme yöntemi kullanılmış ve çalışmaya farklı demografik özelliklere sahip 38 kadın katılmıştır. Araştırma verilerinin toplanmasında veri toplama yöntemi olarak yarı yapılandırılmış görüşme tekniği kullanılmıştır. Görüşme sonucu elde edilen veriler, içerik analizi tekniği ile analiz edilmiştir. Veriler yorumlanırken temalar tespit edilmiştir. Her bir tema ile ilgili kategoriler oluşturulmuştur. Çalışmadan elde edilen sonuçlara göre kadınlar günlük hayatta kurdukları iletişimde çeşitli engellerle karşılaşmaktadırlar. Kadınların günlük hayatta karşılaştıkları iletişim engelleri için; bireysel engeller, korku ve duygusal imalar, sosyo-psikolojik engeller ve dil ile ilgili engeller olmak üzere 4 tema belirlenmiştir. Bu temalar daha sonra kategorilere ayrılmıştır. Bireysel engeller temasında 10 kategori (zihin okuma, hatalı falcllik, felaketleştirme, etiketleme, hemen anlaşılmak isteme, alıngan olma, duyguları ile hareket etme, onay arayıcılık, aşırı soğuk davranma, gizemli olma), korku ve duygusal imalar temasında 8 kategori (yargılayıcı ve suçlayıcı davranılması, aşırı kontrol edilme ve denetlenme, duygulara önem verilmemesi, dedikodu yapılması, lakap takılması, tehdit ve gözdağı verilmesi, karşı cins tarafından baskı hissedilmesi, dinlenilmediğinin hissedilmesi), sosyo-psikolojik engeller temasında 5 kategori (kendini değersiz hissetme, kendini yetersiz hissetme, geçmişe takılma ve şu ana odaklanamama, günah keçisi ilan edilme, çekingen davranma), dil ile ilgili engeller temasında ise 3 kategori (uzun ve karmaşık cümleler kullanma, aşırı abartılı olma, donuk olma) bulunmaktadır.

Anahtar Kelimeler: Kadınlar, iletişim, engel, nitel analiz. 


\section{Giriş}

Kişilerarası iletişim gündelik hayatımızın merkezinde yer alır (Wood, 2010) ve günlük durumlarda başkalarıyla nasıl iletişim kurduğumuzu anlamak için bir çerçeve sağlar (Hartley, 1999). Illetişim kavramı, değişik bilim dallarının ilgi alanlarına girmektedir. Bu özelliğinden dolayı iletişim ile ilgili tek bir tanım yapmak oldukça zordur (Akgöz \& Sezgin, 2009). Ancak temelde herhangi bir iletişim sistemi benzer özellikleri paylaşır (Golen, 1979). İletişimin dört unsuru; iletişim kuran insanların birbirleri ile temas halinde olması, iletişimde bulunan tarafların ortak bir dili veya bir iletişim aracının olması, mesajın açık ve net olarak verilmesi gerektiği ve mesajın alınıp en uygun şekilde anlaşılıp yorumlanması olmak üzere sıralanabilir (Adair, 2016, s.15).

Toplumsal yaşantı içerisinde insanın kendinden önce yaşamış insanların kabullendiği ve süregeldiği kuralları öğrenmesi, inanç ve değerleri benimsemesi ve bunlara uygun olarak bir yaşam sürdürmesi iletişim ile olur (Yatkın \& Yatkın, 2010, s.40). Kişilerarası iletişim, örtüşen mesajların, diğer kişi ve çoklu faktörleri aynı anda etkilediği bir yol olarak tanımlanmaktadır (Griffin 2009, s.58). Bir başka açıdan kişilerarası iletişim toplumsal ortamda iki ya da daha fazla insan arasındaki kelimelerle veya jestlerle bir mesajın bir kişiden diğerine aktarıması sürecidir (Golen, 1979; Tafoya, 1976; Yücel-Bourse \& Bourse, 2012). Seslerin sözcüklere dönüşmesiyle gerçekleşen iletişim türü sözlü iletişim (Demirağ, 2016, s.281) iken, sözsüz iletişim de sadece jestleri ve hareketleri değil, aynı zamanda kıvrım, hacim, giysi, alan ve renk gibi çevresel faktörleri de içerir (Wood, 2009). Tıpkı dil gibi, sözsüz iletişimde diğerleriyle etkileşim yoluyla öğrenilir (Wood, 2009, s.39). Sözsüz iletişim beden hareketlerinin belirli anlamlar yüklenerek sistemleştirilmesiyle ortaya çıkan en eski iletişimsel edinimdir (Demirağ, 2016, s.281).

Birbirimizin farkına varınca başlayan iletişim çok kanallı bir süreçtir. Her bir duyu organı bir iletişim kanalı işlevi görür (Cüceloğlu, 2002, s.55). Bir iletişimde etkililiği gerçekleştirmek amaç olmakla birlikte her zaman ulaşllabilecek bir sonuç değildir. İletilmek istenilen mesajın alıcısına doğru bir şeklide ulaşamamasına yani kişiler arası iletişim engellerine takılmasına bağlı olarak iletişim ağı bozulabilir (Başerer, Başerer \& Demirkaya, 2016), tahrif edilebilir ve yanlış yorumlanabilir (Çedikçi-Elgünler \& Çedikçi-Fener, 2011).

İletişim akışı tek bir alıcıya yönelik, tek yönlü ve dolaysız değildir, iki aşamalı ve dolaylıdır (Maigret, 2014). Illetişim engeli bir insanla diğeri arasındaki bilgi akışına engel olur. Bu engeller bilgiyi gönderen ya da bilgiyi alandan kaynaklanabileceği gibi her ikisini de dışarıda bırakabilir (Golen, 1979). İletişim engelleri çeşitli faktörlerden doğabilir. İletişime engel olan faktörlerden bazıları; fiziksel uzaklık, statü farklıı̆̆ı, cinsiyet farklıkları, kültürel ve dil farklııklarıdır (Tutar \& Yılmaz, 2003, s.64-65). Insanların kişisel arzu ve istekleri, değer yargıları, kültür yapıları, bilgi düzeyleri, içinde bulundukları duygusal ortam, alışkanlıkları, zevkleri ve tutkularının birbirinden farklı olması iletişimin birçok kişisel engelini ortaya çıkarır (Tutar 
\& Yılmaz, 2003, s.68). Ayrıca kişisel engeller, psikolojik engeller, izolasyon, umutsuzluk, gizem, paranoya, ruhsal rahatsızlıklar olarak sıralanabilir (Tafoya, 1976).

İletişim şekillerindeki farklııklar pek çok faktöre bağlanabileceği gibi cinsiyet konusundaki iletişim farklııklarının temel belirleyicisi toplumsal cinsiyet konumlanmasına bağlı olabilir (Thakhathi, 2001). Cinsiyet farklııklarından kaynaklanan özellikler geleneksel toplumlarda önemli bir iletişim engelidir. Geleneksel toplumlarda erkek ve kadınlar çocukluklarından beri farklı rollere göre eğitildikleri için bu durum onların yaşam konusunda farklı tutum ve bakış açıları, farklı iletişim biçimleri geliştirmelerine yol açar (Gökçe, 2006, s.69). Toplumsal cinsiyetle ilgili diğer bir iletişim bariyeri, kadınların kapsayıcı bir iletişimi tercih etmesidir. Kadınlar genellikle, "biz" ve "bizim" gibi, kapsayıcı sözcükleri iletişimlerinde anlaşılıklarından emin olmak ve ilişki kurmak için kullanırlar (Schneider, 2007). Buna ek olarak toplumsal cinsiyete dayalı iletişim farklılıkları birtakım hususlardan etkilenmektedir, bunlardan biri erkekler ve kadınlardaki biyolojik farklııklardır. Büyük biyolojik farklılıklar kromozomları, hormonal dalgalanmaları ve beyin boyutu ve aktivitesini içerir; bunların hepsi dinleme, saldırganlık ve verilerin aktarımı gibi iletişim davranışlarına etki eder (Phillips, Lowe, Lurito, Dzemidzic \& Matthews, 2001; Wood, 2009). Araştırmalar etkili iletişimin anahtar elementlerinden olan dinleme becerisi konusunda kadınlar ve erkekler arasında beyin aktiviteleri açısından da farklılıklar olduğunu göstermektedir (Wood, 2009; Phillips vd., 2001). Kadınların iletişim özellikleri katıımcı olarak tanımlanabilir, kadınların samimi ve canlı bir iletişim şekilleri vardır (Barker \& Zifcak, 1999; Michard \& Viollet, 1991).

Illetişim engelleri değişik şekillerde sınıflandııımışıı (Agarwal, 2010; Cole, 2004; Guffey \& Almonte, 2010; Logo, 2006,). Cole (2004) bu engelleri; bireysel önyargılar ve seçicilik, durum farklılıkları (ast-üst ilişkileri), korku ve duygusal imalar, güven eksikliği, kelime güçlükleri, bilgi yüklemeleri (aşırı anlam yükleme) olarak sıralarken, Agarwall (2010) fiziksel, semantik (dil ile ilgili), organizasyonel, sosyo-psikolojik olmak üzere dört sınıflama yapmıştır. Guffey \& Almonte (2010) bu sınıflamayı, fiziksel, bireysel, dil problemleri, sözel olmayan engeller, aldatıcı dikkat, konuşma yapma engeli olmak üzere yapmıştır. Logo (2006) ise iletişimde kültürel engelleri kendi içinde sınıflandırmıştır.

İyi bir iletişim ilişkiyi geliştirmede kritik öneme sahiptir (Burleson \& Denton, 1997). Iliş̧kisel davranışlar, yardım arayışı, kişilerarası davranış ve iletişimdeki farklııklar hakkındaki kültürel normlar kadınların iletişiminde bir yıpranmaya sebep olur (McHugh \& Bartoszek, 2002, s.119). Bunların yanında kadınlar için oluşturulan basmakalıp yargılar işe alınma ve terfi konularında dahi önlerine çıkan engellerdir (Heilman, 2001). Bu nedenle cinsiyet de iletişimde önemli bir değişken olarak ele alınmaktadır (Korkut-Owen \& Bugay, 2014). Bu açıdan bakıldığında tüm bu süreçlerin kadınların günlük hayattaki iletişimlerine olumsuz etki ettiği düşünülmektedir. Iş̧te bu noktada bu çalışmanın amacı, kadınların günlük hayatta karşılaştıkları iletişim engellerini belirlemektir. 
Bu amaç doğrultusunda aşağıdaki sorulara cevap aranacaktır:

1- Kadınların bireysel iletişim engelleri nelerdir?

2- Kadınların sosyal ve psikolojik iletişim engelleri nelerdir?

3-Kadınların korku ve duygulardan kaynaklanan iletişim engelleri nelerdir?

4-Kadınların dil ile ilgili iletişim engelleri nelerdir?

\section{Yöntem}

\section{Araştırmanın Modeli}

Çalışmada nitel araştırma tekniğinden yararlanılmıştır.

\section{Çalışma Grubu}

Çalışmada amaçlı örnekleme yöntemi kullanılmıştır. Bazı durumlarda örneklem evrenin özellikleri hakkındaki bilgiye dayanılarak ve araştırmanın amacına göre seçilir. Bu tip örneklemeye amaçsal örnekleme adı verilir (Turhanoğlu-Koçak, Suğur, Gönç-Şavran \& Çetin, 2013, s.155). Amaçlı örneklemede örnekleme seçiIen kişilerin ya da objelerin araştırmacının amaçlarına en uygun yanıtı verebilecek birey ve objeler arasından seçilmesi amaçlanır. Seçimde ölçüt kolaylık yanında amaca uygunluktur (Aziz, 1994, s.59). Amaçlı çalışma grubuna kadınların seçim kriteri olarak araştırmaya gönüllü katılmak istemeleri dikkate alınmıştır. Çalışma grubu 38 kadından oluşmaktadır. Araştırmaya katılan kadınları 7'si (\%18.4) 18-22 yaş aralığında, 6'sı (\% 15.8) 23-27 yaş aralığında, 9'u (\%23.7) 28-32 yaş aralığında, 7'si (\% 18.4) 33-37 yaş aralığında, 5'i (\% 13.2) 38-42 yaş aralığında ve 4'ü (\%10.5) 43 yaş ve üzerindedir. Çalışma durumuna göre kadınların 8'i (\%21.1) özel sektörde, 13'ü (\%34.2) kamu kurumunda çalışmaktadır. 10 kişi (\%26.3) ev hanımıdır ve 7'si (\%18.4) öğrencidir. Medeni durumlarına göre kadınların 28'i (\%73.7) evli iken, 10'u (\%26.3) bekârdır. Çocuk sayılarına göre kadınlar 1 çocuğa sahip olanlar 15 kişi (\%39.5), 2 çocuğa sahip olanlar 8 kişi (\%21.1), 3 ve üzeri çocuğa sahip olanlar 4 (\%10.5) kişidir. Hiç çocuğu olmayanlar ise 11 (\%28.9) kişi olarak dağılım göstermektedir.

\section{Yarı Yapılandırılmış Görüşme Tekniği}

Çalışmada veri toplama yöntemi olarak yarı yapılandırılmış görüşme tekniğinden yararlanılmıştır. Yarı yapılandırılmış görüşmede görüşme formunun yarısı yapılandırılmış yarısı yapılandııılmamış bir biçimde hazırlanır. Görüşmecinin görüşme esnasında vereceği tepkilere dayalı olarak açık uçlu görüşme formu esnek bir biçimde hazırlanmış olur (Aypay vd., 2014, s. 151). Katılımcılardan elde edilen veriler yarı yapılandırılmış formlara yazılı olarak alınmıştır. Her bir veri formuna numara verilmiştir.

Nitel araştırmada geçerlilik ve güvenirliği temin etmek için şeffaf bir pro- 
sedür oluşturmak (bir başka araştırmacının ne yapıldığını bilmesi ve kontrol edebilmesi), ifade edilebilir olmak (hem katılımcılar hem de onları kullanmak isteyen diğer araştırmacılar için kategoriler oluşturmak) ve tutarlıık (kategoriler eş zamanlı olarak tutarlı olmalı ve bireysel farklııkları ve kültürdeki gerçek tutarsızlıkları yansıtmalı) gibi özellikler göz önünde bulundurulmalıdır (Rubin \& Rubin, 1995). Kullanılan görüşme formunun geçerliliğini temin etmek için alanında uzman altı öğretim üyesinin görüşlerinden faydalanılmış ve öğretim üyelerinin görüşleri dikkate alınarak yarı yapılandırılmış görüşme formu oluşturulmuştur. Pilot uygulamalar yapıldıktan sonra alınan tüm bu sonuçlara göre görüşme formları uygulama için uygun hâle getirilmiştir.

Bu çalışmada görüşülen kişilerin kendilerini rahat hissetmeleri ve daha samimi cevap vermeleri düşünülerek ses kaydı yapılmamış, önceden hazırlanmış görüşme formu kullanılmıştır.

\section{Verilerin Toplanması}

Kadınlarla yapılan görüşmelerde veri toplamak için araştırmanın amacının ve nasıl yürütüleceğinin açık bir şekilde belirtildiği yazılı görüşme formu kullanımış olup uygulamalar yaklaşık 35-40 dakika almıştır. Araştırmaya 43 kadın katılmış olup bunlar arasından 38'inden elde edilen veriler değerlendirmeye alınmıştır. Çalışmaya katıımda kadınların araştırma için gönüllü olmaları dikkate alınmıştır. Katılımcıların kimliklerinin saklı kalacağı önemle vurgulanmıştır.

\section{Verilerin Analizi ve Yorumlanması}

Verilerin analizinde içerik analizi tekniği kullanılmışıı. İçerik analizi uygulanırken göz önünde bulundurulması gereken prensiplerden biri analiz kategorilerinin açık ve kesin bir şekilde belirtilmesidir (Arık, 1998, s.119-122). Kodlama yapılırken araştırmanın amacı ve görüşme soruları dikkate alınmıştır. Nitel araştırmaların analiz sürecinde kullanılabilecek birçok bilgisayar programı mevcuttur. Bunlardan biride NVivo'dur (Güler, Halıcıoğlu \& Taşğın, 2015, s.45). Bu amaç doğrultusunda Nvivo7 bilgisayar destekli nitel veri analiz programından faydalanılmıştır. Bu çalışmada ilgili literatür göz önünde bulundurularak elde edilen görüşler ışığında, kadınların iletişim engelleri; bireysel iletişim engelleri, korku ve diğer duygusal imalardan kaynaklanan engeller, sosyo-psikolojik engeller ve dil ile ilgili engeller olmak üzere 4 tema belirlenmiştir. Daha sonra bu temalar kategorilere ayrılmış, bu kategoriler ile ilgili katılımcı görüşlerine tablolarda yer verilmiştir.

\section{Bulgular}

Kadınların günlük hayattaki iletişimlerinde karşılaştıkları iletişim engellerinde, kadınların kendi görüşlerinden elde edilen verilere göre 4 tema belirlenmiştir (bireysel iletişim engelleri, korku ve diğer duygusal imalardan kaynaklanan engeller, sosyo-psikolojik engeller ve dil ile ilgili engeller). Bu dört tema daha sonra 
kategorilere ayrılmıştır. Her bir kategori ile ilgili görüşlere yer verilmiştir. Temalar, temalarla ilgili kategoriler, kategorilere ilişkin görüş bildiren kadınların sayısı ve örnek görüşler Tablo 1, Tablo 2, Tablo 3 ve Tablo 4'de ayrıntılı olarak verilmiştir.

\section{Bireysel İletişim Engelleri Teması}

Kadınların bireysel iletişim engelleri temasında 10 kategori bulunmaktadır. Bunlar; zihin okuma (15 kişi), hatalı falcılık (12 kişi), felaketleştirme (13 kişi), etiketleme (15 kişi), hemen anlaşılmak isteme (17 kişi), alıngan olma (20 kişi), duyguları ile hareket etme (24 kişi), onay arayıcılık (34 kişi), aşırı soğuk davranma (12 kişi), gizemli olma (10 kişi) şeklindedir.

Tablo 1. Kadınların İletişim Engellerinden Bireysel Engeller Teması, Kategoriler ve Örnek Görüşler

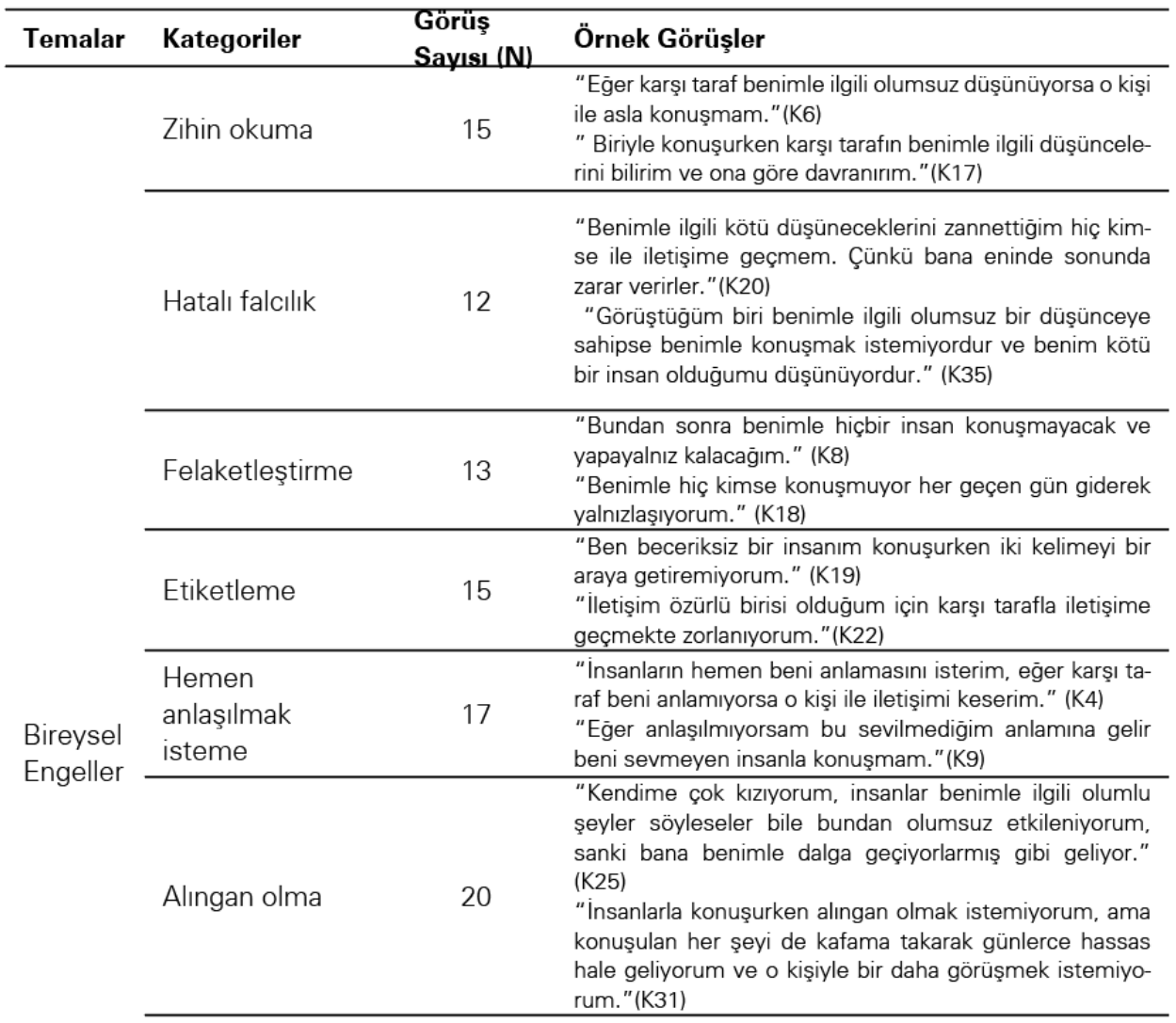




\begin{tabular}{|c|c|c|}
\hline $\begin{array}{l}\text { Duyguları ile } \\
\text { hareket etme }\end{array}$ & 24 & $\begin{array}{l}\text { "Illetişime geçmeden önce, diḡer kişilerden hoşlanıp hoș- } \\
\text { lanmamam iletişimim için önemli bir engeldir." (K2) } \\
\text { "Birini seviyorsam onunla konuşmak için can atarım." } \\
\text { (K11) }\end{array}$ \\
\hline Onay arayıcılık & 34 & $\begin{array}{l}\text { "Elalem ne söylerse ciddi alırım, yapmaya çalışırım, ya- } \\
\text { pamadıḡım zaman çok üzülür ve kendime çok kızarım." } \\
\text { (K27) } \\
\text { "Diḡer insanların görüşlerini çok önemserim, onlardan } \\
\text { onay almak için elimden geleni yaparım." (K29) }\end{array}$ \\
\hline $\begin{array}{l}\text { Aşırı soğuk } \\
\text { davranma }\end{array}$ & 12 & $\begin{array}{l}\text { "Bir türlü diḡer insanlar gibi sıcakkanlı olamıyorum, gü- } \\
\text { lemiyorum ve oldukça soḡuk olduḡum için kendimden } \\
\text { rahatsız oluyorum." (K10) } \\
\text { "İnsanlarla iletişime geçerken ciddi olmak istiyorum ve } \\
\text { aşırı soḡuk davranıyorum, daha sonra bu soḡuk davran- } \\
\text { mak insanları benden uzaklaștırıyor." (K31) }\end{array}$ \\
\hline Gizemli olma & 10 & $\begin{array}{l}\text { "Genelde ser veririm sır vermem, bu benim bir kișilik } \\
\text { özelliḡimdir, diḡer insanların ne düşündüḡü umurumda } \\
\text { deḡil" (K1) } \\
\text { "Sohbet ederken gizemli olurum, insanlar bu halimi me- } \\
\text { rak eder ve bana sürekli soru sorarlar bu da benim hoșu- } \\
\text { ma gider." (K15) }\end{array}$ \\
\hline
\end{tabular}

\section{Korku ve Duygusal İmalar Teması}

Korku ve duygusal imalar temasında 8 kategori bulunmaktadır. Bunlar, yargılayıcı ve suçlayıcı davranılması (29 kişi), aşı kontrol edilme ve denetlenme (24 kişi), duygulara önem verilmemesi (31 kişi), dedikodu yapılması (22 kişi), lakap takılması (16 kişi), tehdit ve gözdağı verilmesi (26 kişi), karşı cins tarafından baskı hissedilmesi (25 kişi), dinlenilmediğinin hissedilmesi (16 kişi) olmak üzere sıralanabilir.

Tablo 2. Kadınların İletişim Engellerinden Korku ve Duygusal İmalar Teması, Kategoriler ve Örnek Görüşler

\begin{tabular}{|c|c|c|c|}
\hline Temalar & Kategoriler & $\begin{array}{l}\text { Görüş } \\
\text { Sayısı (N) }\end{array}$ & Örnek Görüşler \\
\hline \multirow[b]{2}{*}{$\begin{array}{l}\text { Korku ve } \\
\text { Duygusal İmalar }\end{array}$} & Yargılayıcı ve suçlayıcı davranııması & 29 & $\begin{array}{l}\text { "Birisi beni suçlarsa onunla iletișim kurmaktan çekiniyorum ve } \\
\text { ondan uzaklașıorum." (K12) } \\
\text { "İnsanlarla konușmak çok zor, insanlar her konușmamda hata } \\
\text { arıyor ve sanki ben hata yapmıșım gibi beni suçluyor." (K25) }\end{array}$ \\
\hline & Așı kontrol edilme ve denetlenme & 24 & $\begin{array}{l}\text { "Son zamanlarda insanlarla konușmakta zorlanıyorum. İn- } \\
\text { sanlar ne konuşacaḡımı kontrol etmeye çalıșıyor, üstelik her } \\
\text { konușmamdan sonra bana hesap soruyormuș gibi geliyor." } \\
\text { (K14) } \\
\text { "Ben iletișim kurarken insanları kontrol etmiyorum, ama ileti- } \\
\text { șim kurduğum insanlar beni kontrol ediyor, benim insanlarla } \\
\text { nasıl konușacağımı bana ögretmeye çalıșıor ve sürekli keli- } \\
\text { melerimi ve jest ve mimiklerimi nasıl kullanacaḡım konusunda } \\
\text { bana nasihat veriyorlar." (K9) }\end{array}$ \\
\hline
\end{tabular}




\begin{tabular}{|c|c|c|c|}
\hline \multirow{6}{*}{$\begin{array}{l}\text { Korku ve } \\
\text { Duygusal İmalar }\end{array}$} & Duygulara önem verilmemesi & 31 & $\begin{array}{l}\text { "Ben de insanım, karşımdaki insanlar bana robotmuşum gibi } \\
\text { davranıyor, sürekli onları eğlendirmemi ve mutlu etmemi bek- } \\
\text { liyor. Ama ben bunu her zaman yapamam ki. Bazen öfkeli ba- } \\
\text { zen üzüntülü oluyorum bu yaşadıklarımı çevremin anlamasını } \\
\text { bekliyorum." (K10) } \\
\text { "Ben konușurken karșımdaki insanlara deḡer veriyorum } \\
\text { onemsiyorum küçümsemiyorum ama insanlar bana deḡer } \\
\text { vermeyince küçümseyince ve hor görünce çok öfkeleniyorum } \\
\text { bu öfkemden dolayı insanlar benden uzaklașı̀or." (K22) }\end{array}$ \\
\hline & Dedikodu yapılması & 22 & $\begin{array}{l}\text { "İnsanın özeli olur, bu özeli de herkesle paylașmak isteme- } \\
\text { yebilir. Benim özellerimi kim bașkaları ile paylașırsa o insanla } \\
\text { iletișim kurmakta hem çok zorlanııım hem de kuracağım ileti- } \\
\text { șimde hiçbir özelimi anlatmam." (K17) } \\
\text { "İnsanlar birbirlerine her șeyini anlatmamalı, araya bir mesafe } \\
\text { koymalı eḡer araya bir mesafe konulmazsa insanlar bazı özel } \\
\text { paylașımları ve bizim sır olarak adlandırdı̄ımız konuların de- } \\
\text { dikodusunu yapabilir bu da bizi kızdırıp karșı tarafla iletișimi } \\
\text { kesmemize yol açabilir." (K30) }\end{array}$ \\
\hline & Lakap takılması & 16 & $\begin{array}{l}\text { "İnsanlarla iletişim kurarken beni en çok kızdıran birisinin bana } \\
\text { hoș olmayan bir lakap takmasıdır. O kadar çok kızarım ki kapıyı } \\
\text { çarpıp ortamı terk ederim." (K8) } \\
\text { "İnsanlar birbirlerinin arkasından; beceriksiz, șașkın, yetersiz } \\
\text { gibi kelimeleri sıklıkla kullanıyorlar eḡer bu kelimeler bana söy- } \\
\text { lenirse o kișilerle iletișimi keserim." (K20) }\end{array}$ \\
\hline & Tehdit ve gözdağı verilmesi & 26 & $\begin{array}{l}\text { "Illetişimde bir taraf sürekli üstün olmak isteyip karşı tarafı } \\
\text { ezmeye çalısıır, ezerken de çevresine korku salar çevresini } \\
\text { sindirmeye çalıșır ben bu tip insanlarla iletişim kurmak iste- } \\
\text { mem." (K24) } \\
\text { "Bana sürekli baḡıran tehdit ve hakaretler savuran insanlardan } \\
\text { uzak dururum, bu tip insanlar sürekli çevreme zorbalık yapar } \\
\text { ve insanlar da bunlardan kaçarlar." (K33) }\end{array}$ \\
\hline & $\begin{array}{l}\text { Karşı cins tarafından baskı } \\
\text { hissedilmesi }\end{array}$ & 25 & $\begin{array}{l}\text { "İnsanlarla iletişim kurarken erkekler söz konusu olunca çoḡu } \\
\text { zaman çok geriliyorum. Onlar gibi kalın sesle konușamayıp on- } \\
\text { ları ikna edememekten korkuyorum." (K3) } \\
\text { "Bazen erkekler ile iletișim kurarken bazı șeyleri ikinci defa } \\
\text { talep etmekten çekiniyorum. Bu çekinceli durum en fazla er- } \\
\text { kekler olduḡu zaman ortaya çıkıyor." (K16) }\end{array}$ \\
\hline & Dinlenilmediğinin hissedilmesi & 16 & $\begin{array}{l}\text { "Ben konuşurken hiç kimse gözümün içine bakmıyor ve bana } \\
\text { hiç teklifte bulunmuyor." (K23) } \\
\text { "Konuștuḡum zaman hiçbir kimse konuștuklarım ile ilgili bana } \\
\text { soru sormuyor." (K24) }\end{array}$ \\
\hline
\end{tabular}

\section{Sosyo-Psikolojik Engeller Teması}

Sosyo-psikolojik engeller temasında 5 kategori bulunmaktadır. Bunlar; kendini değersiz hissetme (13 kişi), kendini yetersiz hissetme (10 kişi), geçmişe takılma ve şu ana odaklanamama (14 kişi), günah keçisi ilan edilme (8 kişi), çekingen davranma (21 kişi) olmak üzeredir. 
Tablo 3. Kadınların İletişim Engellerinden Sosyo-Psikolojik Engeller Teması, Kategoriler ve Örnek Görüşler

\begin{tabular}{|c|c|c|c|}
\hline Temalar & Kategoriler & $\begin{array}{l}\text { Görüş } \\
\text { Sayısı (N) }\end{array}$ & Örnek Görüşler \\
\hline \multirow{5}{*}{$\begin{array}{l}\text { Sosyo- } \\
\text { Psikolojik } \\
\text { Engeller }\end{array}$} & $\begin{array}{l}\text { Kendini } \\
\text { değersiz } \\
\text { hissetme }\end{array}$ & 13 & $\begin{array}{l}\text { "Ben kendi kendime düşünüyorum insanlar } \\
\text { benimle neden iletişime geçsinler, benimle } \\
\text { insanların konuşmasını anlamıyorum?" (K32) } \\
\text { "İnsanlara anlatacak hiç önemli görüşüm } \\
\text { yok." (K34) }\end{array}$ \\
\hline & $\begin{array}{l}\text { Kendini } \\
\text { yetersiz } \\
\text { hissetme }\end{array}$ & 10 & $\begin{array}{l}\text { "Illetişime geçtiğim insanlarla uzun süre konu- } \\
\text { şacak konu bulamıyorum, bu konuda kendimi } \\
\text { yetersiz hissediyorum." (K38) } \\
\text { "Kendimin entelektüel olduğumu düşünmü- } \\
\text { yorum, kendi kendime düşünüyorum insanlar } \\
\text { benimle neden konuşsun."(K26) }\end{array}$ \\
\hline & $\begin{array}{l}\text { Geçmişe } \\
\text { takılma } \\
\text { ve şu ana } \\
\text { odaklanamama }\end{array}$ & 14 & $\begin{array}{l}\text { "Yakın çevremle iletişim kurarken daha önce } \\
\text { bana söyledikleri olumsuz sözler aklıma geli- } \\
\text { yor, çok üzülüyorum, konuşmak istemiyorum } \\
\text { ve sürekli kafamda geçmişle ilgili kötü sözler } \\
\text { aklıma geliyor." (K1) } \\
\text { "Arkadaşlarımla eğlenmek, konuşmak ve } \\
\text { zevk almak istiyorum, ama geçmişteki kötü- } \\
\text { lükleri aklıma geliyor ve tekrar iletişime geç- } \\
\text { mekten vazgeçiyorum." (K7) }\end{array}$ \\
\hline & $\begin{array}{l}\text { Günah keçisi } \\
\text { ilan edilme }\end{array}$ & 8 & $\begin{array}{l}\text { "İnsanlarla konuşurken bir şeyler ters gider, } \\
\text { bu ters gitmenin nedeni olarak da hep ben gö- } \\
\text { rülürüm." (K6) } \\
\text { "iletişimde bir hata olduğu zaman herkes beni } \\
\text { suçlar, çünkü ben bir günah keçisiyim her şey } \\
\text { benim suçum." (K36) }\end{array}$ \\
\hline & $\begin{array}{l}\text { Çekingen } \\
\text { davranma }\end{array}$ & 21 & $\begin{array}{l}\text { "Bir türlü iletişime geçemiyorum, diğer insan- } \\
\text { lar bana bir şeyler söyler mi diye endişeleniyo- } \\
\text { rum ve içime kapanıyorum." (K3) } \\
\text { "Diğer insanlarla konuşurken eleştirilmekten } \\
\text { korktuğum için sürekli çekingen davranıyo- } \\
\text { rum." (K21) }\end{array}$ \\
\hline
\end{tabular}

\section{Dil ile İlgili Engeller Teması}

Dil ile ilgili engeller temasında 3 kategori bulunmaktadır. Bunlar, uzun ve karmaşık cümleler kullanma (15 kişi), aşırı abartılı olma (16 kişi), donuk olma (11 kişi) olmak üzeredir. 
Tablo 4. Kadınların İletişim Engellerinden Dil ile İlgili Engeller Teması, Kategoriler ve Örnek Görüşler

\begin{tabular}{|c|c|c|c|}
\hline Temalar & Kategoriler & $\begin{array}{l}\text { Görüş } \\
\text { Sayısı (N) }\end{array}$ & Örnek Görüşler \\
\hline \multirow{3}{*}{$\begin{array}{l}\text { Dil ile İlgili } \\
\text { Engeller }\end{array}$} & $\begin{array}{l}\text { Uzun ve } \\
\text { karmaşık } \\
\text { cümleler } \\
\text { kullanma }\end{array}$ & 15 & $\begin{array}{l}\text { "Bir arkadaşım bana soru sorduğunda çok } \\
\text { uzun ve karmaşık cümleler kuruyorum } \\
\text { sonra kendime kızıyorum anlaşılmadığımı } \\
\text { düşünüyorum, ne kadar güzel cümle kurmak } \\
\text { istesem de bir türlü kuramıyorum." (K28) } \\
\text { "Sıkıntı ve endişelerimi anlatmak için uzun } \\
\text { cümleler kuruyorum, daha sonra kendi } \\
\text { kendime düşündügümde kurduğum cümlelerin } \\
\text { ne kadar karmaşı ve anlaşılmaz olduğunu } \\
\text { anlıyorum." (K13) }\end{array}$ \\
\hline & $\begin{array}{l}\text { Aşırı abartılı } \\
\text { olma }\end{array}$ & 16 & $\begin{array}{l}\text { "Konuşurken bir kelimeyi oldukça nazik ve } \\
\text { kibar bir şekilde telaffuz etmeye çalışırım, eğer } \\
\text { o kelimenin İngilizcesini biliyorsam kullanırım, } \\
\text { böyle yaptığım zaman insanların beni daha iyi } \\
\text { fark edeceklerini düšünürüm." (K16) } \\
\text { "Kibar ve nezaketli konuşma hem benim } \\
\text { hoşuma gider hem de karşı tarafın hoşuna } \\
\text { gider." (K30) }\end{array}$ \\
\hline & Donuk olma & 11 & $\begin{array}{l}\text { "Arkadaşlarım bana soru sorduğunda farkına } \\
\text { varmadan donup kalıyorum. Bana neler } \\
\text { olduğunu bende anlamıyorum." (K14) } \\
\text { "Bazen donakalıyorum. Donup kaldığım için } \\
\text { iletişim sırasında kendime çok kızıyorum ama } \\
\text { bu benim huyum olduğunu düşünüyorum." } \\
\text { (K33) }\end{array}$ \\
\hline
\end{tabular}

\section{Tartışma}

Kadınların günlük hayattaki iletişimlerinde karşılaştıkları engeller; kadınların bireysel iletişim engelleri nelerdir, kadınların sosyal ve psikolojik iletişim engelleri nelerdir, kadınların korku ve duygulardan kaynaklanan iletişim engelleri nelerdir ve kadınların dil ile ilgili iletişim engelleri nelerdir, sorularını temel alarak tartışımıştır.

Kadınların günlük hayattaki iletişimlerinde karşılaştıkları engellerden bireysel iletişim engelleri teması altında; onay arayıcılık, duyguları ile hareket etme, alıngan olma, hemen anlaşılmak isteme kategorileri ön plana çıkmaktadır.

Onay aracılık şemasının aktif olduğu kişiler, sürekli olarak "elalem ne der" diye düşünürlerse, kendi duygularını ve düşüncelerini aktif olarak sergileyemezler (Yalçın, Ak, Kavaklı, \& Kesici, 2018). Bu durum da iletişim kurdukları kişi ile iletişim sorunu yaşamalarına sebebiyet verebilir. İletişimi aksatıcı engeller arasında bireylerin yaradıışları gereği mesajlarda seçici davranmaları da vardır (Mısırlı, 2013, s.25). Algılama farklııkları iletişimi engelleyici etkenlerden birisidir. Hedef, kaynağın iletmek istediği her mesajı istenildiği gibi algılamayabilir. Örneğin me- 
saja gerektiği kadar önem ve değer vermiyor olabilir (Mısırlı, 2013, s.26). Karşı tarafın mesaja gereken önemi vermiyor ve beklenen onaylamayı yapmıyor olması onay arayıcı bir alıcı için iletişim engeli oluşturabilir. Onay arayıcııık kadınların iletişimlerinde bu şekilde bir etki yaratabilir.

Eğer bir insan aslında hiçbir etkisi olmadığı halde başkalarının uğradığı sıkıntılardan ortaya çıkan sorunlardan kendisini sorumlu tutuyorsa kişiselleştiriyor, üzerine alınıyor demektir. Bu durum kişilerarası iletişim çatışmalarından biridir ve imalı iletişimden kaynaklanır (Dökmen, 1996). Kendisi ile ilgili olmayan bir sorunu kendi üzerine almak kadınların sıklıkla başvurdukları bir kişiselleştirmedir denilebilir. İşte kadınların alıngan davranıyor olmaları da iletişimi engelleyici bir başka unsuru oluşturabilir.

İletişim sürecinin etkinliğini azaltan en önemli engel, gönderici ve alııının farklı kişilikte olmalarıdır. Kişisel arzu, istek, değer yargıları, kültür düzeyleri, içinde bulundukları duygusal ortam, alışkanlıkları, zevkleri bakımından birbirinden farkı iki insan iletişim sürecinde birçok kişisel engele sahiptir (Akgöz \& Sezgin, 2009; Tutar, Yılmaz \& Eroğlu, 2014). Belirli önyargılar nedeniyle mesajı yanlış değerlendirme kaynağa karşı motivasyon eksikliği ve güvensizlik oluşturabilir. İletişimde bu tür olumsuzlukların yaşanmasına kişisel engeller denilmektedir (Akgöz \& Sezgin, 2009). Tüm bu olasılıkları göz ardı ederek iletişimde ilettiğimiz mesajın hemen algılanması ve anlaşılması beklentisi içine girebiliriz. Kadınların iletişimlerinde hemen anlaşılmak istemesi ve karşı tarafın farkı kişilik özelliklerinden dolayı mesajı algılayamaması iletişim engelinin yaşanmasına sebebiyet verebilir.

Etkili iletişim için kişiler birbirlerinin duygu ve düşüncelerini doğru olarak anlamalıdır. Önemli olan karşıdakinin ne düşündügünü ve hissettiğini dikkate alarak kendi özel yaklaşımını iletişime yansıtmasıdır (Tayfun, 2014). Bir insana sempati duymak o insanın sahip olduğu duygu ve düşüncelerin aynısına sahip olmak demektir. Bir kişiye sempati duyuyorsak onunla birlikte acı çeker, onunla birlikte seviniriz. Belki de en fazla bizimle aynı duyguları paylaşan yakınlarımızın, bizi anlamasını bekleriz (Dökmen, 1996). Duygular yalnızca mesajın aktarılmasını değil, dinlenmesini ve anlaşılmasını da etkiler (Tutar \& Altınöz, 2002; Tutar, Yılmaz \& Eroğlu, 2014, s.65). Bu açıdan bakıldığında kadınların karşı tarafla iletişim kurarken duyguları ile hareket ediyor olmaları ve duygusal imalarda bulunmaları sağlıklı bir iletişimde empatiden ziyade sempatik davranmalarına neden olabilir ki bu durum da iletişimi sekteye uğratabilir.

Korku ve diğer duygusal imalar temasında duygulara önem verilmemesi, tehdit ve gözdağı verilmesi, karşı cins tarafından baskı hissedilmesi, yargılayıcı ve suçlayıcı davranılması, dinlenilmediğini hissetme kategorileri kadınların iletişim engelleri arasında ön plana çıkmaktadır.

Illetişimi engelleyen diğer bir faktör bireyler arası duygu yapılarındaki farklııklardır. İnsan duygusu iletişimde sadece mesajın aktarılmasını değil algılanma- 
sını da etkilemektedir (Mısırlı, 2013, s.34). Insanlarla anlaşmak, bireyin kendisini ifade edip karşısındakileri anlamasını sağlamak, önemsediği ve önemsenmek istediğini göstermek, etkili iletişim becerisi ile sağlanır. Etkili iletişim becerisi kendiliğinden var olan bir yetenek değildir, öğrenilebilir ve geliştirilebilir (Tayfun, 2014). Illetişimin sağlıklı bir biçimde oluşmasına ve sürdürülmesine engel olan faktörler oldukça çeşitlidir. Bu engelleri gidermenin en etkili yolu insanlara "sen varsın, sen benim için değerlisin." mesajının sürekli verilmesidir (Gökçe, 2006, s.70). Beynin hisleri düzenleyen sağ yarım küresi kadınlarda baskın şekilde çalışır. Bu da kadınları duygusal örselenmelere daha yatkın hale getirir (Tarhan, 2010). Bu açıdan değerlendirildiğinde duygularına önem verilmediğini hissetmesi kadınların günlük hayattaki iletişimlerini olumsuz etkileyebilir.

İletişim engelleri iletişimi kuranlar fazlasıyla cinsiyet temelli davranırlarsa da ortaya çıkar (Barker \& Zifcak, 1999). İletişimde beden dili iletişimi, statü ve güç, egemenlik veya teslimiyet durumu gibi faktörler cinsiyete dayalı iletişim engellerini ortaya çıkarır (Tutar, Yılmaz \& Eroğlu, 2014). Bir kadının karşı cins tarafından baskı hissetmesi mesajı iletirken yaşanacak sorunlara sebep olabileceğinden etkin iletişimi sekteye uğratması muhtemeldir (Tutar, Yılmaz \& Eroğlu, 2014). Gerek bireyin kendisinden kaynaklanan gerekse toplumsal cinsiyetin kadına atfettiği rolden kaynaklanan sebeplerle kadınlar karşı cins ile iletişimlerinde farklılık gösterebilirler. Tüm bu sebepler kadınların karşı cins tarafından baskı hissederek iletişime ket vurmasına sebebiyet verebilir.

Konuşmacıya karşı gösterilen ilgi eksikliği de iletişimde engellere örnek verilebilir (Mısırlı, 2013, s.26). İlgi eksikliği mesajı gönderen tarafından dinlenilmediğini hissetme ve mesajın alıcı tarafından alınmadığı düşüncesi oluşturabilir. Bu nedenle tekrar mesaj gönderecek olan gönderici dinlenilmediğini hissettiğinde ilk seferki kadar istekli olmayabilir.

Etkin iletişimin engellerinden birisi de mesajı anlamadan önce onu yargılama ve değerlendirmeye çalışmaktır ve sonucu da çoğunlukla çatışmayla, anlaşmazlıkla sonuçlanmaktadır (Mısırlı, 2013, s.24; Tutar, Yılmaz \& Eroğlu, 2014). Böylelikle karşı tarafın yargılayıcı ve suçlayıcı davranması kadınların iletişimini engelleyebilmektedir.

Sosyo-psikolojik engeller temasında kendini değersiz hissetme, geçmişe takılı kalma, çekingen davranma kategorileri ön plana çıkmaktadır. İnsanlar duymak istediklerini duyar görmek istediklerini görürler. Çoğunlukla insanlar önyargllarının farkında değildirler. Bu önyargılar kültürel geçmişten ya da bireysel değer sisteminden kaynaklanabilir (Cole, 2004). Mesajın alıcısı geçmişe ve önyargılarına takılıp şu ana odaklanamaz ise mesajı yanlış şekilde yorumlayabilir bu durum alıcı ile gönderici arasında bir iletişim engeli oluşturabilir. Ayrıca kadınların diğer insanların olumsuz bir şey söylemesinden ve eleştirilmekten endişe etmeleri de iletişime geçme noktasında isteksiz davranmalarına sebep olabilir. Koşulsuz kabulün önemli bir insan ihtiyacı olduğu (Rogers, 1961) düşünüldüğünde kabul edil- 
memekten korku duymak önemli bir iletişim engeli oluşturabilir.

Dil ile ilgili engeller temasında uzun ve karmaşık cümleler kullanma ve aşırı abartılı olma kategorilerinin ön plana çıktığı görülmektedir. İletişim süreci dil ve anlatım farklııklarından da olumsuz etkilenebilir (Akgöz \& Sezgin, 2009). Kaliteli iletişim sürecinde ne kadar basit, yalın ve açıklayıcı bir dil kullanılırsa, iletişim o kadar sağlıklı işleyecektir (Çedikçi-Elgünler \& Çedikçi-Fener, 2011). Uzun ve karmaşık cümleler kurulması, aşııı abartıı bir dil kullanılması alıcının kullanılan dile aşina olmamasına sebep olabilir ve bu durumlar kadınların günlük hayatta yaşadıkları iletişim engelleri arasında sayılabilir.

\section{Sonuçlar}

Başarılı bir kişilerarası iletişim, psiko-sosyal olgunlaşma ve uyum sürecinde, psikolojik iyilik hali ve kişisel amaçların başarılmasında önemlidir (DeMar, 1997; Riggio \& Zimmerman, 1991). Bu denli önemli bir unsur olan iletişimi etkileyen etmenler arasında ise; iletişim halindeki bireylerin kişilikleri, iletişimin gerçekleştiği fiziksel ve psikolojik ortam ve iletişimin içeriği vardır (Korkut- Owen \& Bugay, 2014).

Kadınlar dünyayı bir ilişki ve bağlantı merceğinden görür (Gilligan, 1982). Sosyo-kültürel nedenlerden dolayı ise, kadınlar genellikle kamusal hayata aktif olarak katılmakta zorlanabilirler (Kameswari, 2002). Buna paralel olarak bazı durumlarda kadınların iletişimde engel yaşamaları söz konusu olabilir (Moitra, 1996). Örneğin, Lakoff (1973)'a göre kadınlar mesajlarını iletirken soru ifadeleri kullanırlar ve kesin olmayan bir ifade şekline sahiptirler. Ayrıca kadınlar daha çok birey odakı iletişime geçerler (Lakoff, 1973). Kadınların iletişiminin belirleyici unsurları arasında ilişkisel ve duygusal konuşmalar sayılabilir (Calnan \& Davidson, 1998; Kissack, 2010).

Bu bağlamda düşünüldüğünde kadınların kendilerine has iletişim tarzlarını sergilerken günlük hayatta karşılaştıkları iletişim engellerini incelemeyi amaç edinen bu çalışmadan elde edilen sonuçlar irdelendiğinde bunlar; bireysel iletişim engelleri, korku ve duygusal imalar, sosyo-psikolojik engeller ve dil ile ilgili engeller olmak üzere temalara ayrılarak incelenmiştir.

Kadınların bireysel iletişim engelleri temasında 10 kategori bulunmaktadır. Bunlar; zihin okuma (15 kişi), hatalı falclık (12 kişi), felaketleştirme (13 kişi), etiketleme (15 kişi), hemen anlaşılmak isteme (17 kişi), alıngan olma (20 kişi), duyguları ile hareket etme (24 kişi), onay arayıcılık (34 kişi), aşırı soğuk davranma (12 kişi), gizemli olma (10 kişi) şeklindedir. Korku ve duygusal imalar temasında 8 kategori bulunmaktadır. Bunlar, yargılayıcı ve suçlayıcı davranılması (29 kişi), aşı kontrol edilme ve denetlenme (24 kişi), duygulara önem verilmemesi (31 kişi), dedikodu yapılması (22 kişi), lakap takılması (16 kişi), tehdit ve gözdağı verilmesi (26 kişi), karşı cins tarafından baskı hissedilmesi (25 kişi), dinlenilmediğinin hissedilmesi 
(16 kişi) olmak üzere sıralanabilir. Sosyo-psikolojik engeller temasında 5 kategori bulunmaktadır. Bunlar; kendini değersiz hissetme (13 kişi), kendini yetersiz hissetme (10 kişi), geçmişe takılma ve şu ana odaklanamama (14 kişi), günah keçisi ilan edilme (8 kişi), çekingen davranma (21 kişi) olmak üzeredir. Dil ile ilgili engeller temasında 3 kategori bulunmaktadır; uzun ve karmaşık cümleler kullanma (15 kişi), aşırı abartıı olma (16 kişi), donuk olma (11 kişi) olmak üzeredir.

Yapılan çalışma sonucundan elde edilen bulgular ışığında kadınların iletişim engelleri literatürde yer alan iletişim engelleri (Barker \& Zifcak, 1999; Mısırlı, 2013; Tutar, Yılmaz \& Eroğlu, 2014) ile paralellik göstermekle birlikte kadınların gerek kişisel özellikleri gerekse mesajı gönderen kişilerin sahip oldukları özellikler sebebiyle günlük hayatta iletişimlerinin engellenebildiği sonucuna ulaşıımıştır.

\section{Kaynakça}

Adair, J. (2016). Etkili iletişim (5.Baskı). İstanbul: Babıali Kültür Yayıncıı̆̆ı.

Agarwal, M. (2010). Business communication. India: Krishna Prakashan Media. Akgöz, E. \& Sezgin, M. (2009). Genel iletişim. Ankara: Gazi Kitabevi.

Arık, A. (1998). Psikolojide bilimsel yöntem (2.Baskı). İstanbul: Çantay Kitabevi.

Aypay, A., Cemaloğlu, N., Sarpkaya, R., Tomul, E., Baştürk, R., Ellez, M., Şahin, B., Yolcu, H., Karakaya, i. \& Turgut, Y. (2014). Bilimsel araştırma yöntemleri (Edt. Abdullah Tanrı̈ğen) (4.Baskı). Ankara: Anı Yayıncılık.

Aziz, A. (1994). Araştırma yöntemleri teknikleri ve iletişim (2. Baskı) Ankara: Turhan Kitabevi.

Başerer, Z., Başerer, D. \& Demirkaya, P. N. (2016). Kişiler arası iletişim engelleri ölçeği geliştirme. Gazi Üniversitesi İletişim Fakültesi Süreli Elektronik Dergi, 43, 290-303.

Barker, R. \& Zifcak, L. (1999). Communication and gender in workplace 2000: Creating a

contextually-based integrated paradigm. Technical Writing and Communication, 29(4), 335-347.

Burleson, B. R., \& Denton, W. H. (1997). The relationship between communication skill and marital satisfaction: Some moderating effects. Journal of Marriage and the Family, 59, 884-902.

Calnan, A. \& Davidson, M. J. (1998). The impact of gender and its interaction with role and status on the use of tag questions in meetings. Gender in Management, 13(1), 19-36.

Cole, G. A. (2004). Management theory and practice (Sixth Edition). London: Geraldine Lyons. 
Cüceloğlu, D. (2002). İletişim donanımları (54.Basım). İstanbul: Remzi Kitabevi.

Çedikçi-Elgünler, T. \& Çedikçi-Fener, T. (2011). Iletişimin kalitesini etkileyen engeller ve bu engellerin giderilmesi. The Turkish Online Journal of Design, Art and Communication, 1 (1), 35-39.

DeMar, J. (1997). A School-based group intervention program to strengthen personal and social competencies in latency-age children. Social Work in Education, 19, 219-230.

Demirağ, A. (2016). Sayısal iletişimin kısa tarihi ve veriler ışığında Türkiye örneği (Edt. Engin Çağlak). Bu Toprakların Illetişim Tarihi. Ankara: Nobel Akademi Yayınclik.

Dökmen, Ü. (1996). İletişim çatışmaları ve empati (4.Basım). İstanbul: Sistem Yayıncilık.

Gilligan, C. (1982). In a different voice: Psychological theory and women's development. Cambridge, Massachusetts: Harvard University Press, 24-39.

Golen, S. P. (1979). An analysis of communication barriers. In public accounting firms. Doctor of Philosophy, Arizona State University, Tempe.

Gökçe, O. (2006). İletişim bilimi insan ilişkilerinin anatomisi. Ankara: Siyasal Kitabevi.

Griffin, E. A. (2009). A first look at communication theory. New York, NY: McGraw Hill.

Guffey, M. E. \& Almonte, R. (2010). Today's Communication Challenges.In Essentials of Business Communication (Sixth Edition). Toronto: Nelson Education, pp. 8-9.

Güler, A., Halıcıoğlu, M. B. \& Taşğın, S. (2015). Sosyal bilimlerde nitel araştırma (2.Baskı). Ankara: Seçkin Yayıncılık.

Hartley, P. (1999). Interpersonal communication (Second edition) Routledge: London.

Heilman, M. E. (2001). Description and prescription: How gender stereotypes prevent women's ascent up the organizational ladder. Journal of Social Issues, $57,657-674$.

Kameswari, V. L. V. (2002). Gendered communication and access to social space: Issues in forest management. Economic and Political Weekly, 37(8), 797-800.

Kissack, H. (2010). Muted voices: A critical look at email in organizations. Journal of European Industrial Training, 34(6), 539-551.

Korkut-Owen, F. \& Bugay, A. (2014). İletişim becerileri ölçeğinin geliştirilmesi: Geçerlik ve güvenirlik çalışması. Mersin Üniversitesi Eğitim Fakültesi Dergisi, 10 (2), 51-64. 
Lakoff, R. (1973). Language and woman's place. Language in Society, 2(1), 4580.

Logo, C. (2006). Race, culture and counselling the ongoing challenge (Second Edition). England: Open University Press.

Maigret, E. (2014). Medya ve iletişim sosyolojisi (4.Baskı) (Çeviren: Halime Yücel). İstanbul: İletişim Yayınları.

McHugh, M. C. \& Bartoszek, T. A. R. (2002). Intimate violence (Edt. Maryka Biaggio and Michel Hersen). In Issues in the Psychology of Women. New York: Kluwer Academic Publishers.

Mısırlı, i. (2013). Genel ve teknik iletişim kavramlar, ilkeler uygulamalar (7.baskı). Ankara: Detay Yayınclık.

Michard, C., \& Viollet, C. (1991). Sex and gender in linguistics: Fifteen years of feminist research in the United States and Germany. Feminist Issues, 53-88.

Moitra, S. (1996). Women, communication and science: Identity question. Economic and Political Weekly, 31(16/17), 39-41.

Phillips, M., Lowe, M., Lurito, J., Dzemidzic, M., \& Matthews, V. (2001). Temporal lobe activation demonstrates sex-based differences during passive listening. Radiology, 220(1), 202-207.

Riggio, R. E. \& Zimmerman, J. (1991). Social skills and interpersonal relationships: Influences on social support and support seeking. Advances in Interpersonal Relationships, 2: 133-155.

Rubin, H. J., \& Rubin, I. S. (1995). Qualitative interviewing: The art of hearing data. Newbury Park, CA: Sage.

Rogers, C. R. (1961). On becoming a person. Boston: Houghton Mifflin Company.

Schneider, J. D. (2007). Effect of gender-related communication differences and awareness of gender-related communication barriers on communication effectiveness. Doctor of Philosophy, Capella University, Minneapolis.

Tafoya, D. W. (1976). Barriers to interpersonal communication: A theory and typology. Doctor of Philosophy, The University of Michigan, Ann Arbor, USA.

Tarhan, N. (2010). Kadın psikolojisi. İstanbul: Nesil Basım Yayın.

Tayfun, R. (2014). Etkili iletişim ve beden dili (5.Baskı). Ankara: Nobel Akademi Yayıncilık.

Thakhathi, T. (2001). Communication strategies of women principals of secondary schools. University of South Africa, ProQuest Dissertations, Ann Arbor.

Tutar, H. \& Altınöz, M. (2002). Büro uygulamaları ve iletişim teknikleri. Ankara: Nobel Yayınları. 
Tutar, H., Yılmaz, M. K. \& Eroğlu, Ö. (2014). Genel ve teknik iletişim (6.Baskı). Ankara: Seçkin yayıncılık.

Turhanoğlu-Koçak, F. A., Suğur, N., Gönç-Şavran, T. \& Çetin, O. B. (2013). Sosyolojide araştırma yöntem ve teknikleri (Edt. Temmuz Gönç Şavran) (2.Baskı). Eskişehir: Anadolu Üniversitesi.

Tutar, H. \& Yılmaz, M. K. (2003). Genel iletişim kavramlar ve modeller (3.Baskı). Ankara: Nobel Yayın Dağıtım.

Wood, J. T. (2009). Gendered lives: Communication, gender, and culture (Eighth edition). Boston: Lyn Uhl.

Wood, J. T. (2010). Interpersonal communication (6.Edition). Boston: Wadsworth Publishing.

Yalçın, S. B., Ak, M., Kavaklı, M. \& Kesici, Ş. (2018). Mutluluğun önündeki engel: Erken dönem uyumsuz şemalar. Bilişsel Davranışçı Psikoterapi ve Araştırmalar Dergisi, 7(1), 7-13.

Yatkın, A. \& Yatkın, Ü. N. (2010). Halkla ilişkiler ve iletişim (3.Baskı). Ankara: Nobel Yayın Dağıtım.

Yücel-Bourse, H. \& Bourse, M. (2012). İletişim bilimlerinin serüveni. İstanbul: Ayrıntı Yayınları. 
